\title{
WED Empowerment For Productive Age Orphanage Through Making Training Empek-Empek
}

\author{
Raden Hasan ${ }^{1}$, Novfitri Landong Namora Sihombing ${ }^{2}$ \\ Institute of Technology and Business Ahmad Dahlan Jakarta \\ novfitri.lns@gmail.com
}

Submitted: February $19^{\text {th }}, 2020 \quad$ Revised: March $12^{\text {th }}, 2020 \quad$ Published: March $30^{\text {th }} 2020$

\begin{abstract}
The purpose of this community service is to provide knowledge to the orphanage the importance of entrepreneurship, anything that can use as a business, how to make a product that will be manufacture and sold, as well as provide training and product marketing strategy generated. Educational entrepreneurship is a conscious effort to change a person's behavior. Educational activities are designed, organized, monitored, and evaluated to be able to achieve the goals set. Therefore, the implementation of education should give priority to dialogue and not as an object in this research conducted on orphans and orphans orphanage is located at Jl. Pajajaran Raya RT 003/005, Village Bencongan Beautiful, Housing III Karawaci. The method used in community service activities is to perform direct training and practice, in this training are given activities that include, presentation materials and practices make empek-empek culinary products presented by direct instructor skilled in the art. The implications of this community service activities are the need for product innovation and should think creatively to obtain products that are creative and innovative while remaining affordable and enjoyable.
\end{abstract}

Keywords: Empowerment, Seniors Productive Entrepreneurship.

\section{INTRODUCTION}

The productive age group today has touched the figure of 40 percent. Own a prolific age group with an average age of about 15-35 years. According to the Inter-Census Population Census (IPS 2015), number Indonesian population will reach 269.6 million in 2020. This amount consists of yet productive age category (0-14 years) of 66.07 million, of reproductive age (15-64 years) 185.34 million, and the period is not fertile (65+ years) 18.2 million. The population of Indonesia projected to continue to grow to 318.96 million by 2045. Based on these data, Indonesia will experience a demographic bonus period up to 2045. Where the number of productive age population more than the fertile community does not (yet productive and unproductive). The number of productive age in 2020 reached $68.75 \%$ of the total population. The abundance of human resources is of childbearing age should be used to improve the quality, either. Both education and skills. The dependency ratio Indonesia amounted to 45.46. That is every 100 people of productive age dependents 46 inhabitants of fertile age.

Increasing the number of childbearing age also adds to the amount of labor in this country. If the numbers continue to rise, it is not impossible if the productive age group will entirely dominate the work in this country. When appropriately managed, workers coming from these groups can help raise the level of productivity of the land(Ma'sum \& Wajdi, 2018). Because the labor childbearing age usually has an advantage both in terms of stamina, physical, as well the level intelligence and creativity. 
WED Empowerment For Productive Age Orphanage Through Making Training Empek-Empek Hasan, Sihombing

To solve it is necessary to have community empowerment for the productive age, while Community empowerment is an attempt to provide power (empowerment) or strengthening (strengthening) to the public. Community empowerment is also defined as the ability of individual bound with local communities to build community empowerment is concerned that aims to find a new alternative in community development efforts to enable and rely on society committed to the effort as empowering, which is to increase the capacity to strengthen the potential or power owned by the public. Retrofitting includes concrete measures such as the provision of various inputs (input) and the opening of access to the multiple opportunities that can make people more and helpless. Community development goal here, namely: Improving life (better living). The level of income and improve the environmental conditions are expected to improve the state of the life of every family and community, community empowerment program that can give children the orphanage that can stimulate the independence of orphans. However, to arrive at that level takes time and mentoring process involving companion who committed to the empowerment of the community. In this case, the Jakarta Institute of Technology Ahmad Dahlan, through devotion people try to stimulate the orphanage care, through training in the culinary business, with the exercise of culinary industry is expected lack of independence orphanage children, guided by lecturers of ITB Ahmad Dahlan Jakarta. Keep in mind, and the culinary business is a business opportunity that is promising and profitable despite having to start with small capital but has the right ideas and strategies by taking into account important factors and strategies in starting a business such culinary

\section{Determine a strategic business location}

These points are essential and support more than 50\% of the success of a culinary business choice. A found place strategic business location not so difficult with the way we are sensitive to the situation and development of the surrounding environment. Food businesses should have to choose a place where the environment is a busy man and has a high purchasing power.

Examples of food business location ideal are like a campus area, offices, terminals, and tourist areas.

\section{Make a place of business that is attractive and comfortable}

The strategic location has owned the next is to think about the consumer interest when looking at the stores, shops, restaurants, or food stalls that you have to wake up. Create a unique feel that they can interest when they first saw it. Never ignore the convenience of visitors because this will provide a sensation that they feel want to come back to visit your place. A create comfortable environmental conditions and attractive culinary efforts include some of which are: cleanliness is the most critical point, not too narrow to sit down and enjoy the food, free air circulation, and give a little entertainment, TV, Music, wifi, etc.

\section{Prioritizing refined taste served}

The taste of food is everything to consumers so that they will assess the quality of your culinary offerings help. For the sake of the culinary business, continuity continues to grow the courage to hire people who are experts in this field, especially cooking. Culinary enthusiast consumers who will be willing to pay more expensive with high-quality flavor. They will never be 
WED Empowerment For Productive Age Orphanage Through Making Training Empek-Empek Hasan, Sihombing

disappointed that then will return to bring other consumers to share in the processed in your place.

Yummy food does not have to be made with expensive materials, considering the small business capital, then make a simple kind of cuisine can still be a promising option.

\section{Selection of the name of the unique culinary business premises}

Naming the shop, restaurant, or cafe with words and terms individual terms that would make a first impression that can make consumers want to try it. Although serving food provided is not common alias is a typical food, but there is no harm if added to the seductive appeal to more consumers. While Orphanage or Children's Social Orphan Child Welfare Institutions also (LKSA) is a social institution nonprofit which accommodates, educate and nurture orphans, orphans strays and neglected children. The orphanage is some sense of them: According to Ministry of Social Affairs (2004:4), Social Orphan children is an institution, the social welfare who have the responsibility to provide social welfare services to children displaced by implementing sponsorship and alleviation of abandoned children, providing services surrogate parent/guardian to meet the physical, mental and social to foster children to obtain ample opportunity, appropriate and adequate for the development of his personality as expected as part of the next generation of the ideals of the nation and as individuals who will participate actively in the field of child protection laws necessary nationalism development in Indonesia is listed in the Act protection of the Child

The orphanage in Indonesia under the supervision Social services, According to the data in central Bureau of Statistics and Social Affairs show that in 2006 the number of abandoned children aged 6-18 years to reach 2,815,393 children, reaching 518296 Abandoned Toddler, Children Treatment One 182 408, 232894 Street Children and Juvenile amounted to 295763. the details of which live in urban areas and rural areas as much as 492281 inhabitants reached $2,275,348$ inhabitants. While classified as vulnerable to neglect estimated at 10,322,764, the details of which live in urban areas reached 2,996,253 rural inhabitants and as many as 7,326,421 people. The condition requires the attention and efforts of the government to realize the system of protection and social welfare services children more representative for the child's development.

The resource empowerment program inline with the goals of Tri Dharma College, where universities role an essential role in influencing changes in society by building a scientific development system to respond to changing global issues by creating training centers for the community by utilizing local resources and wisdom. Selection orphanage Bencongan in Kelapa Dua Village which today is: the absence of regular donors at the orphanage, her many orphanage children who should be financed by the orphanage, lack of expertise possessed by the residents, and the productivity of the residents has not used up.

Of the problems identified, it decided to empower the productive age orphanage by providing training on the culinary business, namely Palembang city empek-empek processing. This community service hopefully will be able to contribute positively to the orphanage.

\section{METHOD}

On the community service is done with a participatory approach in empowering the productive age orphanage. Participation in the program is the empowerment that can stimulate self-reliance, which approaches that are participatory, planned, implemented, monitored, and 
WED Empowerment For Productive Age Orphanage Through Making Training Empek-Empek Hasan, Sihombing

evaluated. However, to arrive at that level takes time and mentoring process involving companion who committed to the empowerment of the community. Community service with the expected participation and their approach: environmental improvement (better environment). In this case, the earnings improvement expected to improve the situation (physical and social); in this case, the environment orphanage. The environmental damage often caused by poverty or a limited income. Besides, it is also empowering the productive age orphanage expected that the improvement of life (better living). Income levels and environmental conditions improved orphanage has expected to improve the state of orphanage life can realize.

Community empowerment has 6 (six) method or steps taken, as follows:

1. The preparation phase, At this stage, two measures must be undertaken, namely:

First, Preparation assistants, namely community development effort taken by ITB Lecturer Ahmad Dahlan Jakarta,

Second, field preparation mostly performed cultivated non-directive. In the court case in question is the location where the empowerment of the community, the community empowerment place in a community service carried out at the orphanageVillage of Bencongan, Kelapa Dua. Tangerang

2. Stages of assessment, At this stage, namely, the assessment process can be done individually at the village orphanage Bencongan, Kelapa Dua. In this case, the officer should attempt to identify the problem needs felt (feel needs) orphanage and also resources of the orphanage. From the results of the identification found that foster children the orphanage are productive age needs to done empowerment so that they become productive so that later there were improvements in the environment and the improvement of life orphanages foster children the orphanage.

3. The planning stage of an alternative program or activity, At this stage the officer as an escort change (exchange agent) in a participatory manner involving residents of the orphanage to try to think about the problems they face and how to overcome them. In this context, the expected high college people can think of several alternative programs and activities that can be done to foster children orphanages.

4. The phase action plan performs. At this stage, the companion changes help foster children orphanages to formulate and determine the programs and activities of what they will do to overcome the existing problems in the orphanage. Besides, also the companion helps to formalize their ideas in written form, primarily when related to the proposal to the funder (In the case of the Institute of Technology and Business Ahmad Dahlan Jakarta as a funder) to realize this community service activity.

5. The implementation stage program. To the community empowerment program implementation role of foster children, the orphanage as a volunteer is expected to sustain the program that has been design to be developed and executed. Cooperation between the companion and foster children orphanages is essential in this stage because sometimes something that has been planned well off the mark when in the field(Wajdi et al., 2018).

6. Evaluation phase, evaluation as a process of supervision of assistant community development program that is running should be done by involving citizens who have specific expertise that can support these activities. With citizen involvement is expected in the short term, usually form a small business. Monitoring is conducted internally by a companion and, for a long time, to build a sustainable business that is larger by utilizing existing resources. 
WED Empowerment For Productive Age Orphanage Through Making Training Empek-Empek Hasan, Sihombing

\section{RESULT AND DISCUSSION}

\section{Linkage Activity}

Duties and load as a lecturer are implementing the college chess dharma without their linkages with other parties, in this case, the anti-upbringing, which has areas where this community service activity performed, providing support in this effort by providing a training ground.

\section{Output Activity}

Exodus Devotion activities in terms of empowering communities through training of childbearing age culinary business at the orphanage. Expected to be the creation of productive entrepreneurs of foster children at the village orphanage Bencongan Tangerang District of Kelapa Dua

\section{Evaluation Activity}

A companion evaluates community service as executor of public activities of the partners of the orphanage, the evaluation made by the method of Kirkpatrick, that is divisible by 4 (four levels):

1. Evaluation level 1 (Reaction)

At this level of success of the training can be evaluated from the reaction or response of participants. Interest and activity of participants in the training to be an indication that the participants can follow the instruction with enthusiasm and passion. There was evident when the training is done all the orphans with wisdom following the training process conducted for one day.

2. Evaluation level 2 (evaluation study)

In this level, measured from the impact on the participants. Is it after the training completed, there is a change from the aspect of knowledge, skills, or work habits for the better, as the purpose of convening the training. In this case, there has been a change in the knowledge, skills, and behavior of orphans. So that orphans know how to become a culinary entrepreneur; change behavior so that after training, they become independent children.

3. Evaluation level 3 (Evaluation of behavior)

This further evaluation process of evaluation level 2 but in this level is more on the results achieved after training, the results obtained are that the orphanage had started to open a small business in the field of culinary.

4. Evaluation level 4 (Evaluation)

Evaluation of training at level 4 emphasis on the outcome (result) after exercise. The results, in this case, that the performance of the orphanage is still not maximized due to capital constraints. Marketing limitations. The limitation period for orphans still a student. So that their productivity is still lacking.

\section{Steps of activity}

The steps undertaken in community service activities are:

\section{Preparation}

In this preparation process there are a few things to do, contact the orphanage, as well as discuss topics that will be conducted later, and determine what products will be made to teach 
WED Empowerment For Productive Age Orphanage Through Making Training Empek-Empek Hasan, Sihombing

the trainee empowerment child childbearing age in an orphanage, then we prepare all ingredients -the material is needs for training

\section{2. presentation Materials}

The content presented associated with the products already agree to be created and taught to the participants, which in this case is the culinary products

\section{3. practice}

After getting an explanation of what is going on training, then subsequently implement the direct exercise of making products that have agreed, making the product simple and easy meals to be understood and simple manufacturing techniques, so it is easy to digest by the trainees.

\section{Closure of the training program}

At the end of activities, the participants and companions reflect the results of the training, where the participants also provide evaluation results on the training undertaken. After completed on what is plan perform well, then from the team leader devotion society closed the training program. The implementation team, community service leave a message to all participants to continue to train and develop the knowledge that has been taught and always trying to creative and innovative in work.

\section{Photos Event}

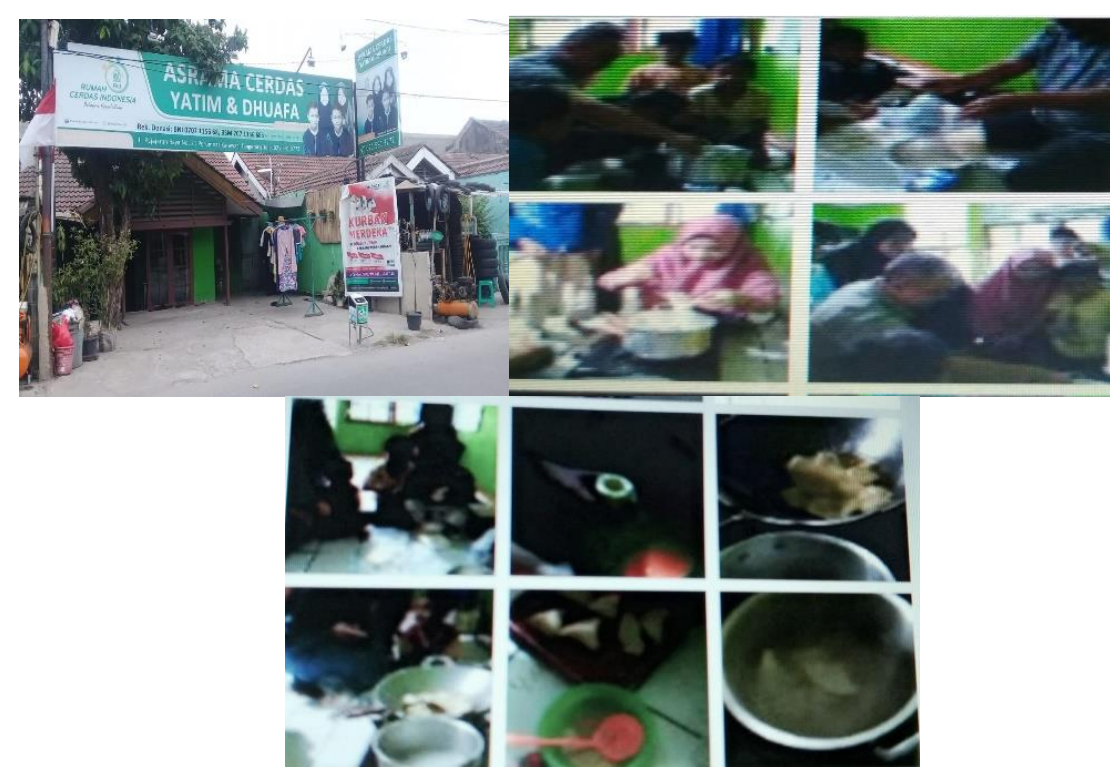

\section{CONCLUSION}

After rundown community service activities in the form of training in the field of culinary at the orphanage, it concludes:

1. The process of manufacture of culinary products implemented in training is: Instructor Explains a material form, to the trainees and continued with the practice, as well as providing an introduction to the trainee what ingredients are use weeks to create the desired culinary products.

2. Equipment and materials used in making culinary desire at the time the practice was, wheat flour, salt fish, cheese, flour custard and bread, eggs. 
WED Empowerment For Productive Age Orphanage Through Making Training Empek-Empek Hasan, Sihombing

3. The policy implication of this activity is the need for product innovation and should think creative so that it can be a creative and innovative product but still enjoyable.

This activity has performed is limited to one orphanage alone and hoped his future could be done again with the number of participants more and involve several orphanages

\section{REFERENCE}

Petter Drucker (1085) Innovation And Entrepreneurship. New York: Harper and Row

Entrepreneurship book (2011) "Building Business Success Since Early Age." Jakarta: Salemba Empat.

Directorate General of Social Empowerment Ministry of Social Affairs of the Republic

Fahrudin, Adi (2012). Empowerment, Participation, and Community Capacity Building. Bandung: Humanities.

Hikmat, Harry (2006). Community Empowerment Strategy. Bandung: Humanities

Ma'sum, T., \& Wajdi, M. B. N. (2018). Pengembangan Kemandirian Pesantren Melalui Program Santripreneur. ENGAGEMENT, 2(2), 221-232.

Mardikanto, Totok (2014) CSR (Corporate Social Responsibility) (Responsibility

Najiati, Sri, et al. (2005). Community Empowerment in Peatland. Bogor: Wetlands International

Suharto, Edi (2005). Building communities to empower people. Bandung: Refika Aditama

Soekanto, Soerjono. Social 1987. An Introduction. Jakarta: Rajawali Press.

Suryana (2001). Kewirausahaan. Jakarta: Salemba Empat.

Wajdi, M. B. N., Duryat, M., Saloom, G., Hariyanto, E., Kurniawan, B., Fielnanda, R., Hartoyo, Z., Nurman, N., Rochmawati, I., \& Fitri, A. (2018). KOMUNITAS OSING, Interaksi Budaya Dan Pembangunan (bunga Rampai Penelitian Etnografi).

Wibisono (2006) Generous. Performance Management: Concepts, Design, and Engineering Company Enhance Competitiveness. Jakarta: Erland 